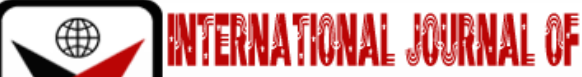

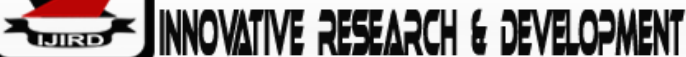

ISSN 2278 - 0211 (Online)

\section{Service Quality Delivery and Consumer's Choice of Fast Foods Outlets in Calabar, Nigeria}

\begin{tabular}{|c|}
\hline Dr. Samuel Etim Ndem \\
Senior Lecturer, Department of Marketing, \\
University of Calabar, Calabar, Nigeria \\
Dr. Beatrice O. Obasiabara \\
Head, School of Postgraduate Studies, \\
Ebonyi State University, Abakaliki, Nigeria \\
\hline
\end{tabular}

\begin{abstract}
:
This study examined service quality delivery and consumers' choice of fast foods outlets in Calabar, Nigeria. It was conducted to highlight how service quality dimensions influenced consumer's choice of fast foods outlets in Calabar, Nigeria. The study specifically examined the effect of service tangibility, service responsiveness, service assurance and service empathy on consumer's choice of fast foods outlets in Calabar. Survey research design was adopted. Primary data was collected from sampled consumers of De Choice Fast Foods and Crunchies in Calabar using structured questionnaire. Simple regression in the Statistical Package for Social Science (SPSS) was adopted to analyse the data collected. Consequently, it was found that service tangibility, service reliability, service responsiveness, service assurance and service empathy had significant effects on consumer's choice of fast foods in Calabar. Based on this finding, it was concluded that service quality dimensions had a significant effect on customers' choice of fast foods in Calabar. Thus, it was recommended amongst others that, fast food outlets in Calabar should be more responsive to consumers' service requirements by rapidly eliciting and resolving consumers' enquiries and complaints; to encourage consumer's choice, fast foods outlets in Calabar should consistently deliver fast, strong, and reliable service; to achieve sustained customer loyalty, fast food outlets should ensure their personnel treat consumers with politeness and consideration at every point of service encounter; more so, every brand should constantly seek ways to offer freshness in order to remain relevant in the market place (Word count: 241).
\end{abstract}

Keywords: Service quality delivery, consumers' choice, fast foods outlets, service quality dimensions

\section{Introduction}

The opening of what can be referred to as the first modern fast-food outlet in Nigeria in 1986, by Mr. Bigg's - a subsidiary of UAC Nigeria, could be regarded as a turning point in the social wellbeing of the citizens as well as a significant landmark in the economic history of the country. Since then, the Nigerian business environment has never remained the same again. It has witnessed and continues to witness the establishment of various fast-food joints, fondly referred to as eateries in virtually all nooks and crannies of the country. A glance at any street corner in Nigeria, now, especially in the urban centres, may likely reveal at least two eateries with their front-lit menu boards jostling for customers' attention. At present, there are over 150 brand names in the country. Also, the South western Nigeria alone accommodates nothing less than 500 outlets of different sizes established by corporate individuals and organizations (Fakokunde, 2010).

Customer's assessment of service quality is a critical information for service providers whose aim is to improve business performance, strengthen core competencies, and position themselves more strategically in the market place (Cronin \& Taylor 1992; Jain \& Gupta 2004). Organizations that provide superior service quality do experience higher economic returns and also have a more satisfied customer base (Aaker\& Jacobson, 1994; Gilbert et al., 2004; Gilbert \&Veloutsou, 2006). Therefore, it has become ubiquitous for service providers to seek out competitive advantages by providing superior service (Lee et al., 2004). According to Zeithaml (1988) service quality is usually defined as the customer's judgement of the overall excellence or superiority of the service. Powers and Barrows (2003) suggested that service is particularly a pivotal or fundamental element in the restaurant sector. In order to measure service quality, Zeithaml and Berry (1998) have developed an instrument called SERVQUAL which consists of five dimensions: reliability, responsiveness, empathy, assurance, and tangibles. While Nikolich and Sparks (1995) have stated that perceived levels of service in restaurants are based on the relationship between customers and service providers.

For Anyanwu (2008), every organization sets out to offer good quality goods and services. As the organizations offer these goods and services to the consumers, they expect reactions from the consumers to confirm or disconfirm the quality of their products. Consequently, consumers use these products overtime, and through their voting power, express 
their views of the various quality levels of the available services or goods in a particular industry. The good quality offerings of a firm bring about good service result, which is how customer satisfaction can affect consumer's choice.

Customer satisfaction is defined as the number of customers, or percentage of total customers, whose reported experience with a firm, its products, or its services (ratings) exceeds specified satisfaction goals. It is seen as a key performance indicator within business and is often part of a balanced scorecard. In a competitive market place, where business competes for customers, customer satisfaction is seen as a key differentiator and increasingly has become a key element of business strategy.

Hence, this study on service quality delivery and consumer's choice of fast foods outlets in Calabar is aimed at ascertaining how the various SERVQUAL dimensions which ranges from Tangibility, Reliability, Responsiveness, Assurance, and Empathy in relation to the service offerings peculiar to the fast food outlets in Calabar (Chrunchies and De Choice) enhances consumer's choice to buy again, to buy other product/services, to become less price sensitive, to remain with a particular fast food outlet and to tell others about their positive experiences with the fast food outlet. This study remains significant in a number of ways, first it is going to contribute to the existing knowledge on service quality and consumer's choice of fast foods outlets. Secondly it remains beneficial to fast food outlets as well as every other organization outside this sector because in today's competitive business environment no organization is willing to let go of any customer, rather they all seek to enlarge their customer base in order to maximize the irreturn on investments. Based on the above, the provision of quality services remains the tool capable of retaining and making the customer of an organization to always return for another purchase.

\subsection{Statement of the Problem}

The consumer's tastes and needs are dynamic, implying that every brand should constantly seek ways to offer freshness in order to remain relevant in the market place. The restaurant industry is no longer divided into clear-cut segments since the services offered do sometimes overlap. Many of the fast-food restaurants offer similar products or services. Therefore, the way and manner their services are provided are critical to gaining competitive edge.

The modern fast-food industry is highly commercialized and characterized by various pre-formulated procedures and food preparation methods usually set up with the intention of minimizing production cost and delivery time. Greater emphasis is always placed in ensuring certain level of flavour and quality consistency of products and quick services as expected by customers. More so, every organization has its goals and objectives, which include setting out to ensure customer satisfaction in their offerings, guiding against obsolescence by being innovative and maximizing profit.

To realize these, the service quality of the organization has to be taken to a higher level: To encourage repeat purchases and customer loyalty, fast track customer patronage and bring about organization's rapid growth, and to guide against service failure and ensure service recovery where failure occurred. The concern here is, little or no attention is paid to the generation and analysis of information about customers encounter and possible ways of dislodging negative dissonance. In specific term, this research work intends to unravel the practical application of service quality dimensions by eateries in Calabar and Nigeria at large. To this end, the statement of the problem for this research work is: How does service quality delivery create an impact on consumer's choice of fast foods outlets in Calabar.

\subsection{Objectives of the Study}

The major objective of this study is to examine service quality delivery and consumer's choice of fast foods outlets

in Calabar, Nigeria. While the specific objective includes:

- To determine the effect of service tangibility on consumer's choice of fast foods outlets in Calabar

- To determine the effect of service reliability on consumer's choice of fast foods outlets in Calabar

- To ascertain the effect of service responsiveness on consumer's choice of fast foods outlets in Calabar

- To determine the effect of service assurance on consumer's choice of fast foods outlets in Calabar

- To determine the effect of service empathy on consumer's choice of fast foods outlets in Calabar

\subsection{Research Hypotheses}

- $\mathrm{HO}_{1}$ : Service tangibles do not have any significant effect on consumer's choice of fast foods outlets in Calabar.

- $\mathrm{HO}_{2}$ : Service reliability does not have any significant effect on consumer's choice of fast foods outlets in Calabar

- $\mathrm{HO}_{3}$ : Service assurance of service does not have any significant effect on consumer's choice of fast foods outlets in Calabar

- $\mathrm{HO}_{4}$ : Service responsiveness of service does not have any significant effect on consumer's choice of fast foods outlets in Calabar

- $\mathrm{HO}_{5}$ : Service empathy does not have any significant effect on consumer's choice of fast foods outlets in Calabar

\section{Literature Review}

\subsection{Theoretical Framework}

The theories which relate to this study include: SERVQUAL model and expected disconfirmation theory (EDT)

\subsubsection{Servqual Model}

Parasuraman, Zeithaml and Berry (1985) postulated the SERVQUAL model. SERVQUAL is presented as a multidimensional construct. In the original formulation, Parasuraman et al. (1985) identified ten components of SERVQUAL; reliability, responsiveness, competence, access, courtesy, communication, credibility, security, 
understanding/knowing the customer, and tangibles. In their 1988 work, these components were collapsed into five dimensions: reliability, assurance, tangibles, empathy, and responsiveness.

The model was used to perform gap analysis of the performance of fast-food outlets service quality against consumer's choice. It was a practically derived method employed by service organizations to enhance service quality. It involves having proper knowledge of the perceived service needs of target consumers. It focuses on the perception of consumers and the relevance of service attributes. This enables firms to use its resources to promote the most critical service attributes.

One major critic of SERVQUAL is that itscentres on disconfirmation paradigm instead of attitudinal paradigm. The model ignores established statistical, economic, and psychological theory. The SERVQUAL dimensions lacks universality. SERVQUAL ignore results of the service encountered by consumers and rather emphasizes on the process of service delivery.

This model is used in evaluating service quality. The dimensions of service quality include: assurance, empathy, reliability, responsiveness, and tangibility. Reliability is the dependability, accuracy, and consistency of performance. In the case of fast foods outlets, it is the dependability, accuracy, and consistency in delivering the needed services or meeting consumer's choice. Tangibility is the physical appearance of element like fast food outlets. Responsiveness is promptness and helpfulness. Empathy means easy access, good communication, convenience and customer understanding. It involves the ease and convenience in assessing quality service delivery which will positively influence consumer's choice of fast food. Assurance involves credibility, security, competence, and courtesy.

While the SERVQUAL has been applied as a benchmark in service quality measurement across different industries and countries, several researchers have criticized heavily this approach from theoretical and practical view (Ladhari, 2008). They have pointed out a number of weaknesses including the use of gap scores, the overlap among five dimensions, shortcomings concerning convergent and discriminant validity, the confusing definition of the 'expectation' construct and unstable dimensionality (Babakus and Boller, 1992; Carman, 1990; Cronin and Taylor, 1992; Buttle, 1996).

Based on the criticisms, a modified version of SERVQUAL was developed (Bougoure and Neu, 2010). Cronin and Taylor (1992) propose SERVPERF or a performance-only instrument of the gap measurement in which the expectation portion in the SERVQUAL model is removed. The SERVPERF instrument has a better performance than the SERVQUAL scale in an overall measure of service quality (Cronin \& Taylor, 1992). Compared to SERVQUAL scale, SERVPERF is able to explain more, if not most of the variance in an overall measure of service quality across four industries; fast food, dry cleaning, banks and pest control (Cronin and Taylor, 1992). Hence, many researchers provide preferential support to the performance-only measures to measure service quality in different service industries (Gilbert et al., 2004; Keillor et al., 2004; Law et al., 2004; Parasuraman et al., 1994). Andaleeb and Conway (2006), Carman (1990) and Olorunniwo et al. (2006) indicate that modification of SERVPERF items is necessary to better fit in various service industries. Consequently, this has motivated researchers to examine other influential variables of service quality within the fast-food industry.

In addition, SERVPERF approach is also selected to measure service quality for a number of reasons. Firstly, a lot of empirical evidence in the literature supports the use of performance perceptions to measure service quality (Cronin et al., 1992). Secondly, performance perceptions have greater reliability and validity compared to the SERVQUAL approach, which compares the difference between customer's expectations and quality perceptions (Parasuraman et al., 1996).

\subsubsection{Expectation Disconfirmation Theory}

The underpinning theoretical framework is drawn from Oliver (1977 and 1980) expectation disconfirmation theory. This theory posits that expectations, coupled with perceived performance, lead to post-purchase satisfaction/choice. This effect is mediated through positive or negative disconfirmation between expectations and performance. If a product/service outperforms expectation post-purchase satisfaction will result (positive disconfirmation). If a product/service falls short of expectations the consumer is likely to be dissatisfied (negative disconfirmation). The dominant model of customer satisfaction is the expectation disconfirmation theory. Disconfirmation theory declares that satisfaction is mainly defined by the gap between perceived performance and expectation which is promising approach to explain satisfaction. The Expectation Confirmation Theory (ECT) also known as expectation disconfirmation theory (EDT) has satisfaction as main dependent factor and expectation and perceived performance as main independent factors. Customer choice is the collection outcome of the customer's perception, evaluation, and psychological reaction to the consumption experience with a product or service (Khalifa\& Liu, 2003). It leads to repeat purchase, loyalty, retention, positive word of mouth and increases long term profitability for the organization and customer (Wirtz, 2003).

Expectations are formed by personal experience and understanding of environment, taking into account practice feasibility based on expectancy theory. Perceived performance is a relatively less influenced estimation of performance based on objective judgement rather than emotional reactions. Expectation disconfirmation occurs in three (3) ways:

- Positive disconfirmation: Occurs when perceived performance exceeds expectations.

- Confirmation: Occurs when perceived performance meets expectations.

- Negative disconfirmation: Occurs when perceived performance does not meet and is less than the expectations.

\subsection{Concept of Service Quality}

Without any doubt, service quality is a very important component in any business-related activity. This is especially so, to marketers a customer's evaluation of service quality and the resulting level of satisfaction are perceived to affect bottom line measures of business success (Cacebuces, et al, 1994). Customer expectations are belief about a service 
that serve as standards against which a service performance is tucked (Zeithaml, et al, 1993), which customer thinks a service provider should offer, rather than on what might be on offer (Parasuraman et al, 1988).

The term service has been defined differently in-service quality literature. For instance, Du Plessis and Rousseau (2003) define services as 'those separately identifiable, essentially intangible activities which provide want-satisfaction and which are not necessarily tied to the sale of a product or another service'. Payne-Palacio and Theis (2001) define services as 'the intangible (untouchable or inconsumable) aspect of the dining out experience'. Powers and Barrows (2003) suggested that service is particularly a pivotal or fundamental element in the restaurant sector, bearing in mind that dining in restaurants is predominantly a social event.

Elliott and Meng (2008) stated that customers of luxury restaurants expect excellent service through courteous and knowledgeable employees. Kivela et al. (1999, 2000 \& 2009) stated that in the restaurant business, customers not only evaluate the quality of food but also the quality of service they encounter during their dining experience. Perceived quality of service is another core determinant of customer satisfaction and behavioral intention. Kivela et al. (1999\& 2000) also proposed that a comprehensive model for dining satisfaction and return patronage in their study indicated that the probability of return patronage was dependent on customers' satisfaction with five aspects of a restaurant namely; first and last impressions, service quality, food quality, ambience quality and feeling comfortable eating there, and reservations and parking.

Ladhari et al. (2008) investigated determinants of dining satisfaction and post-dining behavioral intentions, and concluded that perceived service quality influenced customer satisfaction through both positive and negative emotions. In some studies, it was found that service quality was more important than food quality in dining satisfaction. A study conducted by Yuksel and Yusel (2002) suggested that service quality had significant effect on dining satisfaction at an aggregate market level, and particularly for adventurous or healthy food seekers. Andaleeb and Conway (2006) examined the factors that explained customer satisfaction in the full-service restaurant segment and show their results suggested that compared with food quality/reliability; physical design, price and service responsiveness was the most important contributor to customer satisfaction.

To some, service quality can also be defined as the difference between customers' expectations for the service encounter and the perceptions of the service received. The service quality theory (Oliver, 1980) predicted that customer will judge that quality as 'low' if performance does not meet their expectations and quality as 'high' when performance exceeds expectations.

Closing this gap might require turning-down the expectations or heightening the perception of what has actually been received by the customers (Parasurama et al, 1985). According to Gronoos (1982), perceived quality of a given service is the result of an evaluation process since consumers often make comparison between the service, they expected with perceptions of the service that they received. He concluded that the quality of service is dependent on two variables: expected service and perceived service. Quality speeds superiority or excellence (Taylor and Baker, 1994) or as the consumers overall impression of the relative inferiority/superiority of the organization and its services (Bitner and Hubbert, 1994). Consumer behavioural intentions are also influenced by the standards of service quality (Bitner, 1990).

\subsection{Dimension of Service Quality}

Parasuraman et al. (1985) studied four different types of services including banking industry, credit card companies, motor repair shops, and long-distance telecommunication companies and the results show that service quality had ten (10) dimensions such as reliability, responsiveness, competence, access, courtesy, communication, creditability, security, understanding/knowing the customers and tangibility. However, in 1988, these ten dimensions were cut down to five namely, tangibility, reliability, responsiveness, assurance and empathy. The instrument that is most often used for measuring perceived quality of service in the marketing literature is SERVQUAL (Parasuraman et al., 1988). It consists of the five service dimensions which are tangibles (physical facilities, equipment, and appearance of personnel), reliability (ability to perform the promised service dependably and accurately), responsiveness (willingness to help customers and provide prompt service), assurance (knowledge and courtesy of employees and their ability to inspire trust and confidence) and empathy (caring, individualized attention the firm provides its customers). These dimensions represent how consumers organize information about service quality in their minds. On the basis of exploratory and quantitative research these five dimensions were found relevant for such diverse service settings as fast-food outlets, bank, insurance, appliance repair and maintenance, securities, brokerage, long distance telephone service, automobile repair service and others. The dimensions are also applicable to retail and business services. Sometimes customers will use all of the dimensions to determine services quality perception at other times not.

- Tangibles according to Lee and Johnson (1997) and Zeithaml and Bitner (2003) pertain to the appearance of the establishment's physical facilities, equipment, and personnel. Thus, tangibles are used by restaurants to communicate their image and signal quality to customers. The aforesaid authors concur that services are intangible not only because customers cannot see, feel, smell, hear or taste, but it is also because they are difficult to conceptualize. The intangibility aspect makes services difficult to illustrate, describe, and communicate (Kasapila, 2006). As a result, what a restaurant intends to deliver might be quite different from what the patrons receive (Lee \&Hing, 1995). In addition, the intangibility of services makes it difficult for customers to evaluate or understand the exact nature of services offered (Zikmund\& D'Amico, 2002). Despite the intangibility of services, customers or guests are very much aware of its presence or absence. For example, customers are quick to notice when there is a lack of friendliness or indifference on the part of the waiter or waitress (Payne-Palacio \&Theis, 2001) 
- Reliability refers to the ability of an establishment to offer service dependably and accurately. In its broadest sense, reliability means that an organization delivers on its promises - promises about service provision, pricing, delivery, and problem solving (Jordaan\&Prinsloo, 2001; Lee \& Johnson, 1997; Zeithaml\&Bitner, 2003). In restaurants, reliability may be characterized by adherence to customer requests regarding the preparation of menu items, reservations of tables and accurate billing among others.

- Responsiveness refers to the willingness of service providers to provide prompt service and help customers. This dimension emphasizes attentiveness and promptness in dealing with customer questions, requests, problems and complaints (Lee \& Johnson, 1997; Zeithaml\&Bitner, 2003). Responsiveness is communicated to customers by the length of time they have to wait for assistance, answers to questions, or attention to problems. That is to say that service quality may be enhanced through responsiveness if, for example, patrons are timely assisted with the wine list and menu, or if staff responds appropriately to a customer's request for prompt service (Zeithaml\&Bitner, 2003).

- Assurance relates to the knowledge and courtesy of employees and also their ability to convey confidence and trust. This dimension becomes important when patrons feel uncertain about service offerings of a particular restaurant (Zeithaml\&Bitner, 2003). Assurance may be ensured if, for example, patrons are able to trust the recommendations made by the waiter, feel confident that the food is free from contamination and voice any concern without fear of insult or recrimination.

- Empathy is the caring and individualized attention an establishment provides to its customers like treating customers as individuals. The essence of empathy is by conveying, through personalized service that customers are special and unique (Zeithaml\&Bitner, 2003). Customers want to feel important and understood by the organizations that provide services to them. Employees in restaurants may show empathy to customers by greeting them by name, knowing their dietary requirements / preferences, and being understanding / sympathetic towards their problems (Zeithaml\&Bitner, 2003).

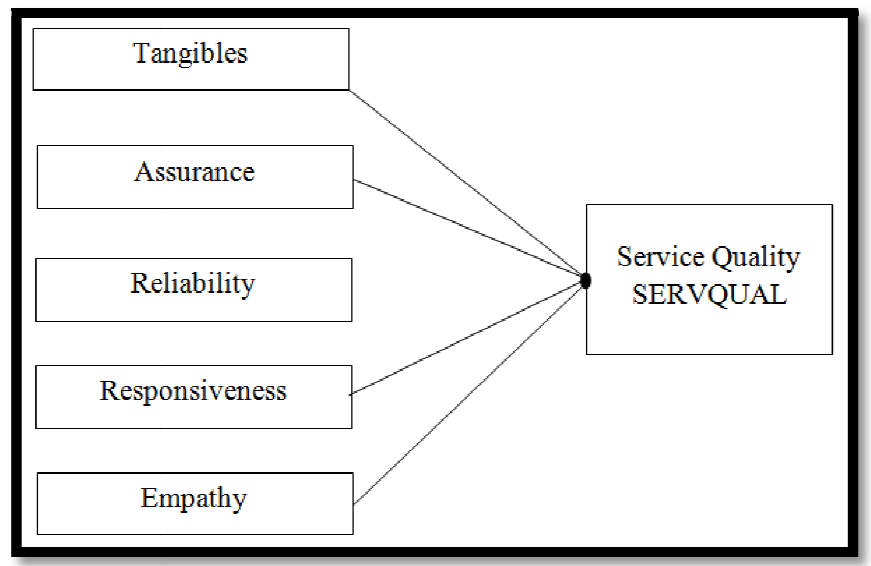

Figure 1: Five Dimensions of Service Quality (SERVQUAL) Source: Parasuraman (1988)

\begin{tabular}{|c|c|}
\hline Dimension & Definition \\
\hline Tangibles & $\begin{array}{l}\text { Appearance of physical facilities, equipment, personnel and } \\
\text { written materials. }\end{array}$ \\
\hline Reliability & $\begin{array}{l}\text { Ability to perform the promised service dependably and } \\
\text { accurately. }\end{array}$ \\
\hline Responsiveness & Willingness to help customers and provide prompt service. \\
\hline Assurance & $\begin{array}{c}\text { Employee's knowledge and courtesy and their ability to inspire } \\
\text { trust and confidence. }\end{array}$ \\
\hline Empathy & $\begin{array}{c}\text { Caring, easy access, good communication, customer } \\
\text { understanding and individualized attention given to customers. }\end{array}$ \\
\hline
\end{tabular}

Zeithaml et al. (1990) proposed a comprehensive perception of quality assessment and claimed that there are other factors apart from the dimensions of Parasuraman et al. (1988). These dimensions of service quality according to him are:

- Access - It includes how easy it is to come into contact with the supplier. This is where position, opening hours, supplier availability and other technical facilities belong.

- Communication - It is the ability to communicate in an understandable way that is natural to customer.

- Credibility - This refers to the ability of being able to trust suppliers.

- $\quad$ Courtesy - This refers to the suppliers' behaviour. Examples are politeness and kindness. 
- However, Parasuraman et al. (1988) assurance dimension is a combination of credibility and courtesy dimension of Zeithaml et al. (1990).

\subsubsection{Classification of Service Quality}

Lewis (1987) suggested that service quality can be classified as;

- Essential subsidiary: Essential refers to the service offered and subsidiary includes factors such as accessibility, convenience of location, availability, timing and flexibility, as well as interactions with the service provider and other customer.

- The core (Contractual) of the service: The core or the outcome quality refers to what is delivered to the customer.

- The related (customer-employee relationship) of the service: This refers to process quality. It is how the service quality is delivered which is the most important element for most services (Gronroose, 1985; McDaugall\&Levesque, 2000; Parasuraman et al., 1991 and Daholker et al., 1996).McDougall and Levesque (2000) in their direct approach investigation on four services forms (dentist clinics, automobile shop, restaurant, and haircut salon), demonstrated that both core rational service quality classes have significant impact on customer satisfaction.

Heskett et al. (1997) conducted studies for several service firms such as airline, restaurants etc, and reported that service quality solely defined as rational quality, has consistent effect on satisfaction and is regarded as key factor in ensuring positive consumer choice and delivering customers satisfaction. Furthermore, Sureschander et al. (2001) identified five factors of service quality which were core service or service product, human element of service delivery, systematization of service delivery, tangibles of services, and social responsibility.

\subsubsection{Benefits of Service Quality}

The benefits of service quality include;

- Retaining customer -High quality builds loyal customers and creates positive word of mouth. It is an important factor in the purchase decision. It determines customer satisfactionwhich in turn affects business and word-ofmouth. Studies have shown that it costs four to six times as much to create a customer as it does to maintain an existing one.

- Avoidance of price competition -A restaurant with a reputation for good quality food and service is in a much stronger competitive position than one with a reputation for inconsistent or poor quality. The restaurant with good image can count on positive word-of-mouth than competitors.

- Retention of good employees -Employees appreciate working in operation that are well run and produce high quality products. When an operation has good quality, it can retain good employees, recruiting is easier and training costs are reduced.

- Reduction of costs - (i)Internal costs: They are those costs that are associated with correcting problems discovered by firm before the product reaches the customers; (ii) External costs: They are those costs associated with errors that the customers experience; (iii) Quality system: This cost is viewed as investment in the future of the company to ensure that customers return.

\subsubsection{Categories of Service Quality}

There are three (3) categories of service quality. These include;

- Technical quality: This refers to what the customer is left with after the customer-employee interactions have been completed.

- Functional quality: It is the process of delivering the same service or product.

- Societal (ethical) quality: It is a credence quality; it cannot be evaluated by the customer before purchase and is often impossible to evaluate after purchase.

\subsubsection{Quality Appraisal in the Fast-Food Industry}

The fast-food industry is a product- offering as well as service-rendering industry. This poses a fundamental challenge for any practitioner in the industry, more so that, service quality is even more difficult to measure, thus, different approaches could be adopted in identifying quality of fast-food products and services. According to Fakokunde (2010), these include:

- The subjective method/objective approach - is based on the individual opinion, and arises from psychological reactions to product/service offering. It is also usually based on personal past experiences and previous trainings. It involves the use of sensory organs to perceive and evaluate product/service quality. Thus, the interpretation or judgement is based on personal preference and may not be an exact recording of the situation Schiffman and Kanuk (1998) offered that the basis for perceptions of product and service quality are usually provided by both the intrinsic and extrinsic characteristics of the product/service. For example, the aroma and colour cues surrounding the operating environment, including the approach and interior decorations all contribute significantly to the assessment of quality service offered by a fast-food operator.

On the other hand, the observation of quality level may entirely exclude personal preferences and attitudes. Instead, quality judgements are purely based on generally accepted and recognized scientific standards. This is referred to as the objective method. Thus, service quality indicators provide the accurate yardsticks in evaluating quality and satisfaction. These are considered as veritable means of measuring the extent to which key service quality factors such as 
the ones proposed in this study are meeting levels of service expectations and satisfaction. In the Nigerian fast-food industry, these may include maintaining a certain level of cleaning, hygiene, nutritive contents etc., as prescribed by a supervisory authority such as NAFDAC, from time to time. Fast food practitioners must therefore strive to continually upgrade their operations in line with these standard operating procedures (SOPs).

- Descriptive approach -This is another perspective from which product quality can be determined or measured. It may be classified as:

- $\quad$ Physical method of measurement, which is concerned with using physical attributes to evaluate product quality such as colour, texture, size etc. For examples, the size and colour decorations of cakes are often used to judge its quality.

- Chemical method of measurement. These are standard methods for the quantitative evaluation of the nutritive value of the product offer. In this case, the extent to which the prepared items such as pizzas, cakes, breads,etc. meet the nutritive content and requirements specified by regulating authorities is used as a basis for quality evaluation of fast-food services.

- Microscopic method of measurement. This requires considerable amount of training and state-of-the-art equipment for product quality to be examined. This is a special method of quality evaluation usually applied in cases involving contamination, adulteration, expiration etc. Stored and frozen foods usually fall under this category.

\subsection{Concept of Customer Choice}

Customer choice refers to the decisions that consumers make with regard to products and services. When we study consumer choice behavior, we examine how consumers decide which products to purchase or consume over time. The theory of consumer choice is the branch of microeconomics that relates preferences to consumption expenditures and to consumer demand curves. It analyzes how consumers maximize the desirability of their consumption as measured by their preferences subject to limitations on their expenditures, by maximizing utility subject to a consumer budget constraint.

According to Tabassum and Rahman (2012), consumers' choice of a particular restaurant depends on many factors which include quality, variation, location, price and environment. While, other authors identify other factors which include ambience (Thakkar \&Thatte, 2014); nutritional value (Goyal\& Singh, 2007) and; hygiene (Alam\& Iqbal, 2007) as influencers. The table below summarizes key findings from previous studies conducted between 1992 and 2014 on influencers of consumer choice in selecting fast food franchise outlets.

\begin{tabular}{|c|c|}
\hline Author & Factors Identified \\
\hline Auty (1992) & $\begin{array}{l}\text { Food type and quality were the most frequently } \\
\text { mentioned factors for dining out, but image and } \\
\text { atmosphere of the restaurant also had the similar }\end{array}$ \\
\hline Carey \&Genevive (1995) & $\begin{array}{c}\text { Ranking } 5 \text { key factors as 1) range of food, 2) quality } \\
\text { of food, 3) price of food, 4) atmosphere, and 5) speed } \\
\text { of service. }\end{array}$ \\
\hline Clark \& Wood (1998) & $\begin{array}{l}\text { Identified food quality, and value as the most } \\
\text { significant factors for restaurant attributes. }\end{array}$ \\
\hline Richards \& Padilla (2009) & $\begin{array}{l}\text { Nutritional profile, vendor identity (brand), the } \\
\text { distance from a consumers' home is considered while } \\
\text { choosing a fast-food restaurant to eat out. }\end{array}$ \\
\hline Islam \&Ullah (2010) & $\begin{array}{l}\text { Identified the factors related to consumer } \\
\text { preferences of fast-food products and found: } \\
\text { Nearness and accessibility; discount and taste; } \\
\text { cleanliness and hygiene; salesmanship and }\end{array}$ \\
\hline Thakkar \&Thatte (2014) & $\begin{array}{l}\text { Consumers attach great importance to various factors } \\
\text { such as quality of food, facility layout, service quality, } \\
\text { speed, and cleanliness. }\end{array}$ \\
\hline
\end{tabular}

Table 2: Studies on Factors Influencing Consumer Choice of Fast-Food Franchise Brand Source: The Researcher, 2021

The findings summarized in the table above highlight the salient factors influencing the choice of consumers when selecting fast food products and outlets.

\subsection{Service Quality and Consumer Choice}

Quality is the overall experience which a customer perceives through interacting with a product and service. Parasuraman et al (1988) has captured the definition of quality taken as a whole as judgement. Service quality has been described as a form of attitude, related but not equivalent to consumer choice that results from the comparison expectation with performance (Parasuraman et al., 1988). Quality has a long-term impact on the choice of consumer. 
Omachanu et al (2008) found that creating value and offering quality service to customers creates loyalty and ensure consumer choice/preference.

Kandampully (1998) say that service loyalty of firm leads to loyal customers. He further found that loyal services offered to customers fulfill both present and future needs of customers. Customer's loyalty and trust is gained by service provider's commitment to provision of quality service.Consumer choice and service quality are interlinked and these create value for customer and help him to make decision whether the service justifies the cost of the service or not. All element of consumer choice has direct bearings on customer satisfaction and value of service (Chau \&Kao, 2009).

Some studies identified four dimensions of service quality,i.e., customer services and navigation and usual design, system reliability, quality of contents and speed of the connection. A positive relationship was found between service quality and consumer choice. The scale for service quality had been observed and critically evaluated as it uses gap scores, measurement of expectations, positively and negatively worded items, the generalization and its dimensions, and the defining a baseline standard for good quality (Oliver, 1993). Some researchers have combined both expectation and perception into a single measure in order to overcome these issues and found that this outperforms the SERVQUAL scale in terms of both validity and reliability (Brown et al, 1993).

There are five specific dimensions of service quality: tangibles, reliability, responsiveness, assurance and empathy (Parasuraman et al, 1988). Cawank et al (2007) says that there are five dimensions of quality: assurance, responsiveness, empathy, reliability and convenience. These dimensions are considered significant for quality concept.

Much research has focused on the relationship between service quality and consumer choice. On a five-point scale, individuals who rate their satisfaction level ' 5 ' are likely to become return customers, and might even evangelize for the food outlet. When a consumer is satisfied with a product, he or she might recommend it to friends, relatives and colleagues. This can be a powerful marketing advantage (Farris, Bendle, Pfeifer\&Reibstein, 2010).

Substantial empirical and theoretical evidence in the literature suggests that there is a direct link between service quality and behavioural intentions (Bitner, 1990; Bolton \&Drew, 1990). Among the various behavioural intentions, considerable emphasis has been placed on the impact of service quality in determining repeat purchase and customer loyalty (Jones \&Farguhar, 2003). As pointed out by Bolton (1998), service quality influences a customer's subsequent behaviour, intentions and choice. When a consumer chooses a fast-food outlet that provides service quality that meets or exceeds his or her expectations, he or she is more likely to choose the same outlet again.

In any organization offering either services or goods, the most important factor for its survival is the customers. If the organization is successful in eliciting satisfaction and, in particular loyalty from its customers, it has paved its way for growth and long-term survival. Satisfied customers will remain longer with the organization, and by talking positively to others and to potential customers about the organization, they will increase interest in the use of their products or services and will attract new customers for the organization. Furthermore, customer loyalty will improve profitability and gain competitive market share (Talebi, Dadashi, Ezzatdoust, \&Farajy, 2012).

Service quality is reflected in a consumer's evaluative perception of an encountered service (Cronin \& Taylor 1992). Zeithaml and Bitner (2000) suggested that consumers judge the quality of a service based on their perceptions of the technical outcome provided, the process by which the outcome is delivered, and the quality of the physical surroundings where the service is delivered. Today, almost all the fast-food outlets focus on several ways to increase their service quality in order to increase the level of satisfaction among their customers and thus increase their purchase intentions as well as loyalty (Qin \&Prybutok, 2008; Gilbert, Veloutson, Goode, \&Moutnho, 2004; Kara, Kaynak, \&Kucukemiroglu, 1995). When fast food outlets are able to achieve or exceed the expectations of customers, the customer will be satisfied with the service, thus influencing consumer's choice.

According to Leon \& Leslie (2006) the degree of satisfaction provided by the goods or services of a firm can be measured by the number of repeat customers. Tat et al. (2011) posits that intense competition and high-quality expectation from customers have forced many fast-food companies do transform from a product- centric approach to a customer centric approach. Therefore, understanding each customer's distinct needs and recent service quality level are essential for fast food outlets to maintain and enhance their competitive edge. A study by Tat et al. (2011) indicated a strong relationship between customers' perceived overall service quality and customer satisfaction. Diners whose experiences match expectations will be satisfied and where their expectations are exceeded, their choice will be positively influenced.

Fakokunde, Iwarere and Mustapha (2014) in a study on 'service quality delivery in the Nigerian fast-food industry: A re-examination of current practices' revealed that the changing socio-cultural pattern witnessed worldwide, especially in developing economies, has brought the fast-food industry into limelight more than ever before. Findings of the study recommend strict application of service quality delivery to ensure positive consumers choice of fast-food outlets. It further came to the conclusion that the industry's activities portend great opportunities for economic development of the country, if properly harnessed.

\subsection{Empirical Findings for Studies on Service Quality and Consumer Choice of Fast-Food Outlets}

\subsubsection{Fast Food Outlet Tangibility and Consumer Choice}

Tangibles comprises of the appearance of physical facilities, including the equipment, personnel, and communication materials available at the point of service delivery. Tangibility is used by restaurants to communicate their image and signal quality to customers.

Lee and Johnson (1997) in a study on Customer expectations for service at appearance retail outlets, investigated Apparel customers' service expectations for discount, off-priced, specialty, and department stores as well as the sources of these expectations. The content and sources of customer service expectations were identified through responses to seven 
open-ended questions during six focus group interviews with students. When shopping for apparel, customers expected services associated with store amenities, store facilities, and sales associates; these expectations varied by the four kinds of apparel retail outlets. The participants identified price, merchandise characteristics, and their moods and personal backgrounds as sources for their expectations. Findings of the study revealed that excellent customer service is often a challenge for consumers. There is little agreement among retailers on what 'customer service' is and which services are important. Identifying which services are most important to consumers means determining what they expect or value when shopping for a particular type of merchandise in a specific retail outlet. In other words of Lee and Johnson (1997), tangibles are used by restaurants to communicate their image and signal quality to customers, thus ensuring consumer choice. The aforesaid authors concur that services are intangible not only because customers cannot see, feel, smell, hear or taste, but it is also because they are difficult to conceptualize. As a result, what a restaurant intends to deliver might be quite different from what the patrons receive (Lee \&Hing, 1995).

Additional evidence can be found in the work of Bougoure and Neu (2010). They studied the relationship between service quality and customer satisfaction in the Malaysian fast-food industry. In that particular study, 300 students from a large Malaysian University in the Blang Valley were asked about their perception on service quality and customer satisfaction in the FFRs in Malaysia. The 29-item DINESERV scale proposed by Stevens et al. (1995), which consists of five dimensions namely tangible, reliability, responsiveness, assurance and empathy, was used in Bougoure and Neu's (2010) study. The findings provide indications that service quality positively influences customer satisfaction among Malaysian fast-food consumers. Thus, it can be concluded that when consumers perceptions towards service quality is positive, customer satisfaction will be more favourable.

\subsubsection{Fast Food Outlet's Reliability and Consumer's Choice}

Reliability is about the accuracy and timelines in the service provided. Reliability means that an organization delivers on its promises - promises about service provision, pricing, delivery, and problem solving (Jordaan\&Prinsloo, 2001). Murad and Ali (2015) conducted a study to investigate service quality and its impact on customer satisfaction in restaurant industry in Pakistan. And also examines how different levels of service quality affects the customer loyalty and its perception according to the particular restaurant. Respondents were chosen from different demographics using random sampling. Restaurant for both fast food and conventional food were selected for this study. Questionnaire technique was used to collect the data and about 152 questionnaires were distributed among people and all were selected for research analysis. Findings indicate that there is a highly significant relationship between service quality (tangibles, assurance, responsiveness, reliability, empathy) and customer satisfaction in restaurant industry.

Timothy, Egene and Richard (2017) carried out a study on service quality and customer satisfaction in Nigerian mobile telephony. A sample of 532 mobile subscribers in Nigeria were used for the study. Pearson Product Correlation Coefficient was used to access the relationship between the variables and test the research hypotheses. Data obtained were analysed using the Statistical Package for Social Science (SPSS), version 20. The study revealed that SERVQUAL reliability dimension has significant effect on customer satisfaction. It was further recommended that with ever-increasing influence of Nigeria communications commission (NCC), and the continuous compliance which is one major strategy that the companies must adopt to remain cost effective.

\subsubsection{FastFood Outlet Responsiveness and Consumer Choice}

Responsiveness is the timely reaction towards the consumer's needs. Munsamy, Chelliah and Mun (2010) in a study on service quality delivery and consumer choice in Malaysia found that responsiveness has relationship but no significant effect on consumer choice. Mhlanga and Tichaawa (2016) carried out a study to determine the factors that affect consumer selection criteria in formal full-service restaurants. The study was based on primary data collected from respondents with the help of structured questionnaires. The questionnaires were administered at selected formal fullservice restaurants in Port Elizabeth. In total, 400 valid responses were included in the statistical analysis. In order to meet the study goals, factor analysis was conducted. Such analysis considered various impact related variables as convenience, to relax, been there before, celebration, business need, social occasion, quality food, good service, good ambience, quietness, and recommendations on selection of formal full-service restaurants. The Statistical Package of Social Sciences (SPSS) software was used to analyse the data. The empirical results suggested that compared with food quality/reliability, physical design and price, service responsiveness was the most important contributor to consumer choice.

A study conducted by Rahhal (2015) on the effects of service quality dimensions on customer satisfaction: An empirical investigation in Syrian mobile telecommunication services; seven service quality dimensions was employed: Reliability, responsiveness, assurance, empathy, tangibles, convenience, complaint handling and network quality. A sample of 460 respondents were used for the study. Findings from the study revealed that service quality dimensions, especially network quality, responsiveness and reliability had direct significant impact on customers' satisfaction. The study concluded that Syrian companies must know how to provide superior network quality which is considered as critical by the respondents in judging the quality of mobile communication services and satisfaction.

\subsubsection{Fast Food Outlets Assurance and Consumer's Choice}

Assurance means being safe. Mumusang, Chelliah and Mum (2010) found that assurance has positive relationship with consumer's choice but without significant effect. Omar, Ariffin and Ahmad (2015) in a quantitative study aimed at providing additional insight into the relationship between service quality and consumer choice by examining the moderating effect of consumer's gender in Arabic restaurants and to identify the extent of each service quality attributes in relation with consumer choice as they are perceived by Malaysian customers. A quantitative study was conducted and a 
set of questionnaires examining the attributes of service quality and customer satisfaction was developed. The data was collected through the survey completed by 411 respondents. Correlation analysis and hierarchical regressions were employed to analyse the data. The correlation analysis shows that all the five service quality attributes - tangibles, reliability, responsiveness, assurance and empathy have positive relationship with customer satisfaction. Findings of the correlation analysis showed that all the five service quality attributes - tangibles, reliability, responsiveness, assurance and empathy have positive relationship with consumer choice.

Al-Tit (2015) in a study on 'The Effect of Service and Food Quality on Customer Satisfaction and Hence Customer Retention' investigated the relationships between service quality, food quality, customer satisfaction, and customer retention in limited-service restaurants in Jordan. A questionnaire-based survey was distributed to 400 students served at 10 limited-service restaurants in the neighbourhood of universities in Amman, the capital city of Jordan. Service quality was measured in terms of SERVQUAL attributes. The key dimensions of food quality, customer satisfaction and customer retention were identified through literature. Of the data collected, 283 valid copies of questionnaire were analysed using SPSS 20.0. The findings showed that service quality and food quality have a positive influence on customer satisfaction. In addition, service quality dimensions besides customer satisfaction have a positive influence on customer retention. Finally, the results confirmed that customer satisfaction mediates the relationship between service quality and customer retention.

\subsubsection{Fast Food Outlet Empathy and Consumer Choice}

Empathy entails the provision of caring, individualized attention to customers during a service encounter. The essence of empathy is by conveying, through personalized service, that customers are special and unique (Zeithaml\&Bitner, 2003). Employees in restaurants may show empathy to customers by greeting them by name, knowing their dietary requirements/preferences, and being understanding/sympathetic towards their problems (Zeithaml\&Bitner, 2003). Ajobo (2012) in his study to assess the perceptions of customers about service quality in selected fast-food restaurants in Asaba using a total of 180 customers out of which 120 were found useable noted that empathy dimension contributed the highest perception level in service quality. This is also consistent with the study by Chow and Luk (2005) where they claimed that customers regarded empathy as the highest priority in assessing service quality of a fast-food restaurant, because it provides caring, individualized attention, approachability, as well as understanding the needs of customers.

Omar, Ariffinb and Ahmad (2015) conducted a study on Service Quality, Customers' Satisfaction and the Moderating Effects of Gender: A Study of Arabic Restaurants. The study aimed at providing additional insight into the relationship between service quality and customer satisfaction by examining the moderating effect of customers' gender in Arabic restaurants and to identify the extent of each service quality attributes in relation with customer satisfaction as they are perceived by Malaysian customers. A quantitative study was conducted and a set of questionnaires examining the attributes of service quality and customer satisfaction was developed. The data was collected through the survey completed by 411 respondents. Correlation analysis and hierarchical regressions were employed to analyse the data. The correlation analysis shows that all the five service quality attributes - tangibles, reliability, responsiveness, assurance and empathy have positive relationship with customer satisfaction. However, hierarchical regressions indicated a slightly different result. The attributes-tangibles, assurance and empathy are found to have significant relationship with customer satisfaction, but the relationship with the other two attributes - reliability and responsiveness is insignificant. It also revealed that empathy has a strong positive correlation with customers' satisfaction while responsiveness has a weak positive relation with customers' satisfaction.

\section{Methodology}

\subsection{Research Design}

A survey research design was used in this study by collecting data through questionnaire from the population of interest.

\subsection{The Study Area}

This research is based on service quality delivery and consumer's choice of fast foods outlets in Calabar, Nigeria (a case study of De Choice Fast Foods and Crunchies). The survey was carried out in Calabar, Cross River State. Cross River State is located in the South-South region of Nigeria. Specifically, the survey will be carried out in Calabar Metropolis. Calabar Metropolis comprises of Calabar South and Calabar Municipality. Calabar Metropolis was chosen because a large proportion of fast-food outlets are resident within this region of the state. The inhabitants of Calabar Metropolis are hospitable and a large proportion of person residing here are civil servants and students.

\subsection{The Population of the Study}

The population of the study comprises of all the customers (consumers) of De Choice Fast Foods and Chrunchies who are major fast-food outlets in Calabar. However, there are no accurate data on the number of customers in these two outlets. 


\subsection{Sampling Design and Procedures}

The simple random sampling method was used in which case it is a subset of individuals (a sample) chosen from a larger set (a population). In this method, each individual is chosen randomly and entirely by chance, such that each individual has the same probability of being chosen at any stage during the sampling process.

\subsection{Sampling Size}

Due to lack of official data on the accurate number of consumers of the product and services of the two fast food outlets in Calabar, the researcher conveniently chooses to use a sample size of 100 customers (50 from each fast-food outlet) in the study areas and the administration of the questionnaire was done using a convenience sampling technique.

\subsection{Sources of Data And Data Collection Method}

According to Etuk (2010), data collection is the process through which the researcher searches for information to help him solve the problem on hand. Every research effort thus centers on search for information either from primary or secondary sources. Primary data was obtained directly from the source. In which case, direct interviews and observations were made with the respondents as well as the use of questionnaires; therefore, primary data was obtained in the field.

\subsection{Data Collection Instruments}

Questionnaire was the major instrument for data collection. Questionnaire contains self-administered questions that are both structured and semi structured formalized questions used in the survey to collect information which is later analyzed to provide results necessary for solving a given research problem. The researcher used self-administered questionnaires. The scale of measurement for the questionnaire are Nominal, Ordinal and Interval variables respectively asthese allowed respondents to choose from alternative that were provided by the researcher.

\subsection{Data Treatment Techniques}

The data treatment will be done using the simple regression analysis. This is because we are trying to establish the relationship amongst the variables (dependent and independent), which helps us to understand how the typical value of the dependent variable changes with the independent variable being varied.The regression models involve the following variables:

- The unknown parameters ' $\beta$ '

- The independent variables ' $\mathrm{X}$ ' and

- The dependent variable ' $Y$ '

Hence the formula:y $\approx \mathrm{f}(\mathrm{X}, \beta)$

\section{Results}

- Hypothesis 1: Service tangibles do not have any significant effect on consumer's choice of fast-food outlets in Calabar.

\begin{tabular}{|c|c|c|c|c|}
\hline Model & R & R Square & Adjusted R Square & Std. Error of the Estimate \\
\hline 1 & $.725^{\mathrm{a}}$ & .526 & .521 & .79564 \\
\hline \multicolumn{5}{|c}{ a. Predictors: (Constant), Tangibility } \\
\hline
\end{tabular}

Table 3: Model Summary Showing the Relationship between Service Tangibility and Consumer's Choice of Fast-Food Outlets in Calabar

\begin{tabular}{|c|c|c|c|c|c|c|}
\hline \multicolumn{2}{|c|}{ Model } & Sum of Squares & Df & Mean Square & F & Sig. \\
\hline \multirow{3}{*}{1} & Regression & 65.275 & 1 & 65.275 & 103.113 & $.000^{\mathrm{b}}$ \\
\cline { 2 - 7 } & Residual & 58.873 & 93 & .633 & & \\
\cline { 2 - 7 } & Total & 124.147 & 94 & & & \\
\hline \multicolumn{7}{|c|}{ a. Dependent Variable: Consumers' choice } \\
\hline \multicolumn{7}{|c|}{ b. Predictors: (Constant), Tangibility } \\
\end{tabular}

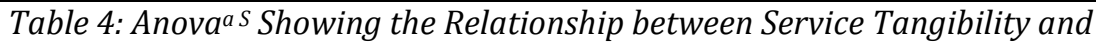
Consumer's Choice of Fast-Food Outlets in Calabar

\begin{tabular}{|c|c|c|c|c|c|c|}
\hline \multirow{2}{*}{ Model } & \multicolumn{2}{|c|}{$\begin{array}{c}\text { Unstandardized } \\
\text { Coefficients }\end{array}$} & $\begin{array}{c}\text { Standardized } \\
\text { Coefficients }\end{array}$ & \multirow{2}{*}{ Sig. } & \\
\cline { 3 - 5 } \multicolumn{2}{|c|}{} & B & Std. Error & Beta & & \\
\hline \multirow{2}{*}{1} & (Constant) & 2.057 & .406 & & 5.067 & .000 \\
\cline { 2 - 5 } & Tangibility & .635 & .063 & .725 & 10.154 & .000 \\
\hline \multicolumn{7}{|c|}{ a. Dependent Variable: Consumers' choice } \\
\hline
\end{tabular}

Table 5: Coefficients ${ }^{a}$ showing the Relationship between Service Tangibility and Consumer's

Choice of Fast-Food Outlets in Calabar

Tables 3, 4 and 5 above report the results of regression analysis carried out to test Hypothesis 1 . The results show that Service tangibles do have significant effect on consumer's choice of fast-food outlets in Calabar.(b $=2.057, p<0.05)$. 
Therefore, Hypothesis 1 is rejected. Tables 4 and 5 further report a significant $F$ statistic, indicating the model's strong prediction strength $\left(\mathrm{F}=103.113, \mathrm{R}^{2}=72.5 \%, \mathrm{p}<0.05\right)$. The $\mathrm{R}^{2}$ of 72.5 per cent implies that for every unit change in consumer's choice of fast food, 72.5 per cent of such variation is attributed to Service tangibles.

- Hypothesis 2:Service reliability does not have any significant effect on consumer's choice of fast-food outlets in Calabar

\begin{tabular}{|c|c|c|c|c|}
\hline Model & R & R square & Adjusted R square & Std. Error of the Estimate \\
\hline 1 & $.631^{\mathrm{a}}$ & .398 & .392 & .89613 \\
\hline \multicolumn{5}{|r|}{ a. Predictors: (Constant), Reliability } \\
\hline
\end{tabular}

Table 6: Model Summary Showing the Relationship between Service Reliability and Consumer's Choice of Fast-Food Outlets in Calabar

\begin{tabular}{|c|c|c|c|c|c|c|}
\hline \multicolumn{2}{|c|}{ Model } & Sum of Squares & Df & Mean Square & F & Sig. \\
\hline \multirow{3}{*}{1} & Regression & 49.463 & 1 & 49.463 & 61.594 & $.000^{\mathrm{b}}$ \\
\cline { 2 - 7 } & Residual & 74.684 & 93 & .803 & & \\
\cline { 2 - 7 } & Total & 124.147 & 94 & & \\
\hline \multicolumn{6}{|r|}{ a. Dependent Variable: Consumers' choice } \\
\hline
\end{tabular}

Table 7: Anova ${ }^{a}$ Showing the Relationship between Service Reliability and Consumer's

Choice of Fast-Food Outlets in Calabar

\begin{tabular}{|c|c|c|c|c|c|c|}
\hline \multirow{2}{*}{\multicolumn{2}{|c|}{ Model }} & \multicolumn{2}{|c|}{$\begin{array}{l}\text { Unstandardized } \\
\text { Coefficients }\end{array}$} & \multirow{2}{*}{$\begin{array}{c}\text { Standardized } \\
\text { Coefficients } \\
\text { Beta } \\
\end{array}$} & \multirow[t]{2}{*}{$\mathbf{T}$} & \multirow[t]{2}{*}{ Sig. } \\
\hline & & $\mathrm{B}$ & Std. Error & & & \\
\hline \multirow[t]{2}{*}{1} & (Constant) & 2.891 & .418 & & 6.908 & .000 \\
\hline & Reliability & .519 & .066 & .631 & 7.848 & .000 \\
\hline a. & \multicolumn{6}{|c|}{ Dependent Variable: Consumers' choice } \\
\hline
\end{tabular}

Tables 6, 7 and 8 above report the results of regression analysis carried out to test Hypothesis 2 . The results show that Service reliability does have significant effect on consumer's choice of fast-food outlets in Calabar. $(b=2.891, p<0.05)$. Therefore, Hypothesis 2 is rejected. Tables 7 and 8further report a significant $F$ statistic, indicating the model's strong prediction strength $\left(F=61.594, R^{2}=63.1 \%, p<0.05\right)$. The $R^{2}$ of 63.1 per cent implies that for every unit change in consumer's choice of fast food, 63.1 per cent of such variation is attributed to Service reliability.

- Hypothesis 3: Service responsiveness does not have any significant effect on consumer's choice of fast-food outlets in Calabar.

\begin{tabular}{|c|c|c|c|c|}
\hline Model & R & R square & Adjusted R square & Std. error of the estimate \\
\hline 1 & $.764^{\mathrm{a}}$ & .584 & .580 & .74507 \\
\hline \multicolumn{5}{|c|}{ a. Predictors: (Constant), Responsiveness } \\
\hline
\end{tabular}

Table 9: Model Summary Showing the Relationship between Service Responsiveness and Consumer's Choice of Fast-Food Outlets in Calabar

\begin{tabular}{|c|c|c|c|c|c|c|}
\hline \multicolumn{2}{|c|}{ Model } & Sum of Squares & Df & Mean Square & F & Sig. \\
\hline \multirow{3}{*}{1} & Regression & 72.521 & 1 & 72.521 & 130.639 & $.000^{\mathrm{b}}$ \\
\cline { 2 - 7 } & Residual & 51.627 & 93 & .555 & & \\
\cline { 2 - 6 } & Total & 124.147 & 94 & & \\
\hline \multicolumn{7}{|c|}{ a. Dependent Variable: Consumers' choice } \\
\hline
\end{tabular}

Table 10: Anova ${ }^{a}$ Showing the Relationship between Service Responsiveness and Consumer's Choice of Fast-Food Outlets in Calabar

\begin{tabular}{|c|c|c|c|c|c|c|}
\hline & \multirow[t]{2}{*}{ Model } & \multicolumn{2}{|c|}{$\begin{array}{l}\text { Unstandardized } \\
\text { Coefficients }\end{array}$} & \multirow{2}{*}{$\begin{array}{c}\begin{array}{c}\text { Standardized } \\
\text { Coefficients }\end{array} \\
\text { Beta } \\
\end{array}$} & \multirow[t]{2}{*}{$\mathbf{t}$} & \multirow[t]{2}{*}{ Sig. } \\
\hline & & $\mathrm{B}$ & Std. Error & & & \\
\hline \multirow[t]{2}{*}{1} & (Constant) & 1.311 & .425 & & 3.082 & .003 \\
\hline & Responsiveness & .786 & .069 & .764 & 11.430 & .000 \\
\hline
\end{tabular}

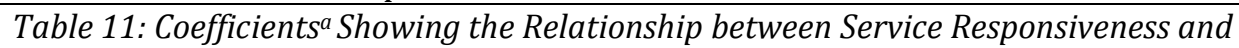
Consumer's Choice of Fast-Food Outlets in Calabar 
Tables 9, 10 and 11 above report the results of regression analysis carried out to test Hypothesis 3. The results show that Service responsiveness have significant effect on consumer's choice of fast-food outlets in Calabar.(b $=1.311, \mathrm{p}<$ 0.05). Therefore, Hypothesis 3 is rejected. Tables 10 and 11 further report a significant $F$ statistic, indicating the model's strong prediction strength $\left(F=130.639, R^{2}=76.4 \%, p<0.05\right)$. The $\mathrm{R}^{2}$ of 76.4 per cent implies that for every unit change in consumer's choice of fast food, 76.4 per cent of such variation is attributed to service responsiveness.

- Hypothesis 4: Service assurance does not have any significant effect on consumer's choice of fast-food outlets in Calabar.

\begin{tabular}{|c|c|c|c|c|}
\hline Model & R & R Square & Adjusted R Square & Std. Error of the Estimate \\
\hline 1 & $.534^{\mathrm{a}}$ & .285 & .278 & .97671 \\
\hline \multicolumn{5}{|c|}{ a. Predictors: (Constant), Assurance } \\
\hline
\end{tabular}

Table 12: Model Summary Showing the Relationship between Service Assurance and Consumer's Choice of Fast-Food Outlets in Calabar

\begin{tabular}{|l|c|c|c|c|c|c|}
\hline \multicolumn{2}{|c|}{ Model } & Sum of Squares & Df & Mean Square & F & Sig. \\
\hline \multirow{3}{*}{1} & Regression & 35.429 & 1 & 35.429 & 37.139 & $.000^{\mathrm{b}}$ \\
\cline { 2 - 7 } & Residual & 88.718 & 93 & .954 & & \\
\cline { 2 - 7 } & Total & 124.147 & 94 & & \\
\hline \multicolumn{6}{|c|}{ a. Dependent Variable: Consumers' choice } \\
\hline \multicolumn{6}{|c|}{ b. Predictors: (Constant), Assurance } \\
\hline
\end{tabular}

Table 13: Anova ${ }^{a}$ Showing the Relationship between Service Assurance and Consumer's Choice of Fast-Food Outlets in Calabar

\begin{tabular}{|c|c|c|c|c|c|c|}
\hline \multicolumn{2}{|c|}{ Model } & \multicolumn{2}{|c|}{$\begin{array}{c}\text { Unstandardized } \\
\text { Coefficients }\end{array}$} & $\begin{array}{c}\text { Standardized } \\
\text { Coefficients }\end{array}$ & \multirow{2}{*}{ T } & \\
\cline { 3 - 5 } \multicolumn{2}{|c|}{} & B & Std. Error & Beta & & \\
\hline \multirow{2}{*}{1} & (Constant) & 3.351 & .461 & & 7.263 & .000 \\
\cline { 2 - 6 } & Assurance & .439 & .072 & .534 & 6.094 & .000 \\
\hline \multicolumn{7}{|c|}{ a. Dependent Variable: Consumers' choice } \\
\hline
\end{tabular}

Table 14: Coefficients ${ }^{a}$ Showing the Relationship between Service Assurance and Consumer's Choice of Fast-Food Outlets in Calabar

Tables 12, 13 and 14 above report the results of regression analysis carried out to test Hypothesis 4 . The results show that service assurance have significant effect on consumer's choice of fast-food outlets in Calabar. (b $=3.351, \mathrm{p}<$ 0.05). Therefore, Hypothesis 4 is rejected. Tables 13 and 14 further report a significant $F$ statistic, indicating the model's strong prediction strength $\left(F=37.139, \mathrm{R}^{2}=53.4 \%, \mathrm{p}<0.05\right)$. The $\mathrm{R}^{2}$ of 53.4 per cent implies that for every unit change in consumer's choice of fast food, 53.4 per cent of such variation is attributed to service assurance.

- Hypothesis 5:Service empathy does not have any significant effect on consumer's choice of fast-food outlets in Calabar.

\begin{tabular}{|c|c|c|c|c|}
\hline Model & R & R Square & Adjusted R Square & Std. Error of the Estimate \\
\hline 1 & $.455^{\mathrm{a}}$ & .207 & .199 & 1.02859 \\
\hline \multicolumn{5}{|c|}{ a. Predictors: (Constant), Empathy } \\
\hline
\end{tabular}

Table 15: Model Summary Showing the Relationship between Service Empathy and Consumer's Choice of Fast-Food Outlets in Calabar

\begin{tabular}{|c|c|c|c|c|c|c|}
\hline \multicolumn{2}{|c|}{ Model } & Sum of Squares & Df & Mean Square & F & Sig. \\
\hline \multirow{3}{*}{1} & Regression & 25.754 & 1 & 25.754 & 24.343 & $.000^{\mathrm{b}}$ \\
\cline { 2 - 6 } & Residual & 98.393 & 93 & 1.058 & & \\
\cline { 2 - 6 } & Total & 124.147 & 94 & & \\
\hline \multicolumn{6}{|c|}{ a. Dependent Variable: Consumers' choice } \\
\hline \multicolumn{7}{|r|}{ b. Predictors: (Constant), Empathy } \\
\hline
\end{tabular}

Table 16: Anova ${ }^{a}$ Showing the Relationship between Service Empathy and Consumer's

Choice of Fast-Food Outlets in Calabar

\begin{tabular}{|c|c|c|c|c|c|c|}
\hline \multirow{2}{*}{\multicolumn{2}{|c|}{ Model }} & \multicolumn{2}{|c|}{$\begin{array}{l}\text { Unstandardized } \\
\text { Coefficients }\end{array}$} & $\begin{array}{c}\text { Standardized } \\
\text { Coefficients }\end{array}$ & \multirow[t]{2}{*}{$T$} & \multirow[t]{2}{*}{ Sig. } \\
\hline & & B & Std. Error & Beta & & \\
\hline \multirow[t]{2}{*}{1} & (Constant) & 3.780 & .481 & & 7.860 & .000 \\
\hline & Empathy & .395 & .080 & .455 & 4.934 & .000 \\
\hline \multicolumn{7}{|c|}{ a. Dependent Variable: Consumers' choice } \\
\hline
\end{tabular}

Table 17: Coefficients ${ }^{a}$ Showing the Relationship between Service Empathy and Consumer's Choice of Fast-Food Outlets in Calabar 
Tables 15, 16 and 17 above report the results of regression analysis carried out to test Hypothesis 5. The results show that service empathy does have significant effect on consumer's choice of fast-food outlets in Calabar. $(b=3.780, \mathrm{p}<$ 0.05). Therefore, Hypothesis 5 is rejected. Tables 16 and 17 further report a significant $F$ statistic, indicating the model's strong prediction strength $\left(F=24.343, R^{2}=45.5 \%, p<0.05\right)$. The $\mathrm{R}^{2}$ of 45.5 per cent implies that for every unit change in consumer's choice of fast food, 45.5 per cent of such variation is attributed to service empathy.

\subsection{Summary of Findings}

On testing the four research hypotheses developed for this study, the following findings were arrived at from the analysis of the data collected:

- Service tangibles have significant effect on consumer's choice of fast foods outlets in Calabar.

- Service reliability have significant effect on consumer's choice of fast foods outlets in Calabar

- Service responsiveness have significant effect on consumer's choice of fast foods outlets in Calabar

- Service assurance have significant effect on consumer's choice of fast foods outlets in Calabar

- Service empathy have significant effect on consumer's choice of fast foods outlets in Calabar

\section{Conclusion and Recommendations}

\subsection{Conclusion}

This study examined the effect of service quality delivery on consumer's choice of fast foods outlets in Calabar, Nigeria by analyzing primary data collected from sampled consumers of fast foods outlets in Calabar. The results obtained from the study indicate that service quality delivery in terms of tangibles, reliability, assurance, responsiveness as well as empathy significantly influence consumer's choice of fast foods outlets in Calabar. Hence, in order to improve and ultimately maintain consumer's choice/preference, fast foods outlets must improve the quality of their service delivery by consistently paying attention to these five (5) critical services qualities dimensions: tangibility, reliability, responsiveness, assurance, and service quality empathy.

\subsection{Recommendations}

In line with the findings of this study, the following recommendations are made:

- To encourage consumer's choice, fast foods outlets in Calabar should consistently deliver fast, strong and reliable service.

- $\quad$ Fast food outlets in Calabar should be more responsive to consumers' service requirements by rapidly eliciting and resolving consumers' enquiries and complaints.

- To achieve sustained customer loyalty, fast foods outlets should ensure their personnel treat consumers with politeness and consideration at every point of service encounter.

- Fast foods outlets should ensure that the appearance of physical facilities at their outlets is appropriate in order to provide confidence to consumers in their ability to provide the service required.

- The consumer's tastes and needs are dynamic; thus, every brand should constantly seek ways to offer freshness in order to remain relevant in a competitive market place.

\section{References}

i. Aaker, D. A., \& Jacobson, R. (1994). The financial information content of perceived quality. Journal of Marketing Research, 31 (2), 191-201.7.

ii. Ajobo, 0. (2012) Customer perception of service quality, a critique. Total Quality Management, 12 (8), $111-124$.

iii. Al-Tit, 0. (2015). The Effect of Service and Food Quality on Customer Satisfaction and Hence Customer Retention. Retrieved from https://www.researchgate.net/publication/282128914_The_Effect_of_Service_and_Food_Quality_on_Customer_ Satisfaction_and_Hence_Customer_Retention

iv. Andaleeb, S. S., \& Conway, C. (2006). Customer satisfaction in the restaurant industry: An examination of the transaction-specific model. Journal of Services Marketing, 20 (1), 3-11.

v. Anyanwu, N. (2008). Monetary Economics: Theory, Policy and Institutions. Onitsha: Hybrid Publishers

vi. Auty, S. (1992). Consumer Choice and Segmentation in the Restaurant Industry. The Service Industries Journal, $12,324-339$

vii. Babakus, E. \&Boller, G. W. (1992). An empirical assessment of the SERVQUAL scale. Retrieved fromhttps://econpapers.repec.org/ article/eeejbrese/v_3a24_3ay_3a1992_3ai_3a3_3ap_3a253-268.htm

viii. Bitner, M. J. (1990). Evaluating service encounters: The effects of physical surroundings and employee responses. Journal of Marketing, 54 (2), 69 - 82.

ix. Bitner, M. J., \&Hubbert, A. R. (1994). Encounter satisfaction versus overall satisfaction versus service quality: the consumer's voice. Thousand Oaks, CA: Saga Publications.

x. Bolton, R. N. \& Drew, J. H.(1990). A multi stage model of consumer assessments of service quality and value. Journal of Consumer Research. 17 (4), 375-385.

xi. Bolton, R. N. (1998). A dynamic model of the duration of the customer's relationship with a continuous service provider. Marketing Science, 17 (1), 45-66.

xii. Bougoure, U. \&Neu, M. (2010). The relationship between service quality and customer satisfaction in the Malaysian fast-food industry. Retrieved from 
https://www.tandfonline.com/doi/abs/10.1080/153329610036043

xiii. Chow, I.H.S. \&Luk, O. L. (2005). Service quality in restaurant operations in China: Decision and experience-oriented perspectives. Hospitality Management, 26 (3), 698-7 10.

xiv. Cronin, J. J., Tailor, K. \& Steven, A. (1992). Measuring service quality: A re-examination and extension. Journal of Marketing, 56 (3), 55-68.

xv. Du Plessis, P. J. \& Rousseau, G. G. (2003). Buyer behaviour: A multi-cultural approach (3rd ed.). Cape Town: Oxford University Press Southern Africa.

xvi. Elliott, K. M. \&Meng, J. G. (2008). Predictors of relationship quality for luxury restaurants. Journal of Retailing and Consumer Services, 15, 509-5 15.

xvii. Etuk, J. E. (2010). Business research methods: Concepts, processes and applications. Calabar: University of Calabar Press.

xviii. Fakokunde, P., Iwarere, N. \& Mustapha, U. (2014). Service quality delivery in the Nigerian fast-food industry: A reexamination of current practices. Retrieved from http://www.epints.sunway.edu.my/46/1/ 1serviequality.

xix. Fakokunde, T.O. (2010). Quality Control and Improvement Practices among Fast Food Retail Outlets in Southwestern Nigeria

xx. Farris, P. W., Neil, T. B., Philip, E. P., \& David, J. R. (2010). Marketing metrics: The definitive guide to measuring marketing performance. Upper Saddle River, New Jersey.

xxi. Gilbert, G. R. \&Veloutsou, C. (2006). A cross-industry comparison of customer satisfaction. The Journal of Services Marketing, 20 (5), 298-308.

xxii. Goyal, A. \& Singh, N.P. (2007) Consumer Perception About Fast Food in India: An Exploratory Study. British Food Journal, 109 (2), 137-51.

xxiii. Gronoos, C. (1982). A service quality model and marketing implications. European Journal of Marketing, 4, 36-44.

xxiv.Heskett, J. L., Sasser, W. E. \& Schlesinger, L. A. (1997). The service profit chain. New York: Free Press

xxv. Jain, S. K. \& Gupta, G. (2004). Measuring Service Quality: SERVQUAL vs. SERVPERF Scales. Vikalpa, 29 (2), 25-37.

xxvi. Jones, H. \&Farguhar, J. D. (2003). Contact management and customer loyalty. Journal of Financial Services Marketing, 8 (1), 71-78.

xxvii. Jordaan, Y. \&Prinsloo, M. (2001). Grasping service marketing. Pretoria Grapevine News.

xxviii. Kara, A., Kaynak, E., \&Kucukemiroglu, O. (1995). Marketing strategies for fast-food restaurants: A customer view. International Journal of Contemporary Hospitality Management, 7 (4), 16-22.

xxix. Kasapila, W. (2006). Young adults' satisfaction regarding their dining experience in casual dining restaurants in hatfield. Pretoria: Victory Press.

xxx. Kivela, J., \&Crotts, J. C. (2009). Understanding Travelers' Experiences of Gastronomy through Etymology and Narration. Journal of Hospitality and Tourism Research, 33(2), 161-192.

xxxi. Kivela, Robert, I., \& John, R. (1999). Consumer research in the restaurant environment, Part 1: A conceptual model of dining satisfaction and return patronage. International Journal of Contemporary Hospitality Management, 11(5), 205-222.

xxxii. Ladhari, R. (2008). A review of twenty years of SERVQUAL research. Journal of Quality and Service Sciences, 1: 172-198.

xxxiii. Ladhari, R. Brun, I., \& Morales, M., (2008). Determinants of dining satisfaction and post dining behavioral intentions. International Journal of Hospitality Management, 27 (4), 563-573.

xxxiv. Lee, M. Y. \& Johnson, K. K. P. (1997). Customer expectations for service at appearance retail outlets. Journal of Family and Consumer Sciences, 4(89), 26-29.

xxxv. Lee, Y. L., Hing, N. (1995). Measuring quality in restaurant operations: An Application of the SERVQUAL instrument. International Journal of Hospitality Management, 4 (14), 293-3 10.

xxxvi. Mhlanga, O. \&Tichaawa, G. (2016). Factors that affect consumer selection criteria in formal full-service restaurants.

xxxvii. Munsamy, J., Chelliah, S. \&Mun, H. (2010). Service quality delivery and consumer choice in Malaysia. Retrieved from http://ijimt.org/papers/71-M461.pdf

xxxviii. Munsamy, J., Chelliah, S., \&Mun, H. W. (2010) Service Quality Delivery and Its Impact on Customer Satisfaction in Malaysia. International Journal of Innovation Management and Technology, 1 (4), 398-404.

xxxix. Murad, I. \& Ali, Y. (2015). Service quality and its impact on customer satisfaction in restaurant industry in Pakistan. Retrieved from https://valleyinternational.net/index.php/theijsshi/article/view/113

xl. Nikolich, M. A. \& Sparks, B. A. (1995). The hospitality service encounter: the role of communication. Journal of Hospitality \& Tourism Research, 19 (2), 43-56.

xli. Oliver, R. (1993). Satisfaction: A behavioural perspective on the consumer. New York: McGraw-Hill.

xlii. Oliver, R. L. (1980). Measurement and education of satisfaction processes in retail settings. Journal of Retailing, 57 (3), 25-48.

xliii. Omar, M. S., Ariffinb, H. F. \& Ahmad, R. (2015). Service Quality, Customers' Satisfaction and the Moderating Effects of Gender: A Study of Arabic Restaurants. Retrieved from

https://www.researchgate.net/publication/305394423_service_quality_customers'_satisfaction_and_the_mode rating_effects_of_gender_a_study_of_arabic_restaurants 
xliv. Parasuraman, A., Berry, L. and Zeithaml, A. (1991). Refinement and reassessment of the SERVQUAL scale. Journal of Retailing, 64 (4), 420-450.

xlv. Parasuraman, A., Zeithaml, A. \& Berry, L. (1988) SERVQUAL: a multi-item scale for measuring consumer perceptions of the service quality. Journal of Retailing, 64, (1), 12-40.

xlvi. Parasuraman, A., Zeithaml, V. A. \& Berry, L. L. (1985). A conceptual model of service quality and its implications for future research. Journal of Marketing, 49: 41-50.

xlvii. Payne -Palacio, J., \&Theis, M. (2001). Introduction to foodservice. New York: Prentice Hall.

xlviii. Powers, T. \& Barrows, C. W. (2003). Introduction to management in the hospitality Industry. New York: John Wiley \& Sons.

xlix. Qin, H. \&Prybutok, V. R. (2008). Determinants of customer -perceived service quality in fast-food restaurants and their relationship to customer satisfaction and behavioral intentions. Quality Management Journal, 15 (2), 35-50.

l. Rahhal (2015). Effects of service quality dimensions on customer satisfaction: An empirical investigation in Syrian mobile telecommunication services. International Journal of Business and Commerce, 2 (12): 1-14.

li. Richards, 0. \& Padilla, M. (2009). Effect of food experience on tourist satisfaction: the case of Indonesia. International Journal of Culture, Tourism and Hospitality Research, 10 (3), 272-282.

lii. Schiffman, L.G. \&Kanuk, L. L.(1998).Consumer Behaviour.6 ${ }^{\text {th }}$ Edition. New Delhi, Prentice-Hall.

liii. Sureschander, G. S., Ranjendran, C. \&Anatharaman, R. N. (2002). The relationship between service quality and customer satisfaction - A factor specific approach. Journal of Service Marketing, 16, (4):363-379.

liv. Talebi, N. K., Dadashi, O. L. \&Ezzatdouf, G. K. (2012). Analyzing the impact of service quality dimension of customer satisfaction and loyalty in the hospital industry of Iran. International Journal of Academic Research in Management Sciences, 3 (3), 1-9.

lv. Timothy, P., Egene, U. \& Richard, I. (2017). Service quality and customer satisfaction in Nigerian mobile telephony. Retrieved from https://valleyinternational.net/index.php/theijsshi/article/view/113

lvi. Yuksel, A., \&Yusel, F. (2002). Measurement of tourist satisfaction with restaurant services: A segmentbased approach. Journal of Vacation Marketing, 9 (1), 52-68.

lvii. Zeethemal, V., Parasuraman, A. \& Berry, L. (1990). Delivering Quality Service: Balancing Customer Perceptions and Expectations.New York: The Free Press.

lviii. Zeithaml, V. A., \&Bitner, M. J. (2003). Services marketing: Integrating customer focus across the firm (3rd ed.). Boston, New York: McGraw-Hill

lix. Zeithaml, V. A., (1988). Consumer perceptions of price, quality and value: a means end model and synthesis of evidence. Journal of Marketing, 52, 2-22.

lx. Zeithaml, V. A., Berry, L. L. \&Parasuraman, A. (1998). Communication and control processes in the delivery of service quality. Journal of Marketing, 52, 35-48.

lxi. Zeithaml, V., Benry, L. and Parasuraman, A. (1996). The Behavioural Consequences of Service Quality. Journal of Marketing, 60:31-46. 